\title{
Analysis and Reference of Environmental cost Management in $Y$ Enterprise
}

\author{
Lijun Bu \\ School of Accounting, Harbin University of Commerce, Harbin 150028, China \\ bulijun@126.com
}

Keywords: economic growth, environmental pollution, environmental cost management.

\begin{abstract}
Environment pollution problem is more and more serious currently. Enterprises, as individuals making important contribution to economic growth, also can lead to environmental pollution. In the paper, Environmental cost management of Y enterprise is analyzed, and experience and reference are proposed on the basis of describing the necessity of environmental cost management.
\end{abstract}

\section{Necessity of environmental cost management}

Environmental cost management refers that environmental costs are included into the scope of enterprise operation cost on the basis of traditional cost management, therefore environmental cost produced during product service life process undergoes a series of scientific management work, such as forecasting, decision-making, control, accounting, analysis, assessment and so on organically and systematically.

China belongs to a resource-rich country with high consumption of petrochemical energy. It is also a country with serious pollution. Therefore, China must pay attention to synchronous development of economy and environment. Enterprise can achieve durable environment cost leading advance through environmental cost management, thereby achieving efficient utilization of resources, reducing resource loss and waste emission, realizing win-win situation of economic benefit and environment benefit.

\section{Y Enterprise and fertilizer industry}

Y Chemical Co., Ltd. is mainly engaged in production and sales of fertilizers and chemical products. It is an important agriculture supporting backbone enterprise in H Province. Fertilizer is the major product in the enterprise.

Fertilizer is mainly divided into four categories of nitrogen fertilizer, phosphate fertilizer, potash fertilizer and compound fertilizer. Nitrogen fertilizer mainly refers to urea in China. Urea production in China has always been in the leading position all over the world. Fertilizer production depends on consumption of a lot of energy and resources. Meanwhile, many pollutants are also produced during fertilizer production and application. Fertilizer production is highly dependent on the consumption of resources and energy. In 2011, energy consumed in Chinese chemical fertilizer production was equivalent to about 110 million tons of standard coal, which accounted for about 3\% or so in national energy consumption. Coal for fertilizer production mainly included high-quality anthracite (accounting for 55\% of national high-quality coal). Electricity consumed for fertilizer production was about 6.4 billion $\mathrm{KWH}$, which accounted for $3 \%$ of national electricity consumption. Consumed gas was about 10.9 billion cubic meters, which accounted for $30 \%$ of total national consumption. $80 \%$ sulfur resources in China were consumed for fertilizer production. A lot of pollutants also can be produced during the production process of fertilizer, which can affect environment. A lot of pollutants produced during the production process are also discharged to environment, which not only can pollute soil and air, but also can make a lot of water resources lose use function since they are higher than grade 5 water quality standards for surface water. In addition, NH3, N2O, C02 and 
similar materials are emitted due to application of farmland nitrogen fertilizer, thereby intensifying the greenhouse effect.

\section{Data analysis of environment cost management in Y Enterprise}

1.Definition of molecules in indicators: Energy consumption has been generally identified by most enterprises. It is the most representative indicator, which is followed by water resource consumption and greenhouse gas emission indicators.

2.Quantification of molecules: environmental performance indicators which can finally represent environmental problems are indicated. Since the environmental indicators disclosed by enterprises in the environmental report are mostly based on physical quantity as unit without additive property, we must calculate the 'contribution' of enterprises in the aspects of resource consumption, water resource depletion, solid and liquid waste disposal. Environmental indicators should be quantified for facilitating indicator calculation.

1) Energy purchased by enterprises and primary energy investment are different concepts aiming at conversion of non-renewable energy. We use a conversion coefficient in order to add the used energy conveniently for calculating all primary energy quantity consumed by enterprises. All energies used by enterprises are converted into primary non-renewable energy. Since there is no standard conversion coefficient temporarily in China temporarily, European non-renewable primary energy conversion coefficient is adopted in the paper.

\begin{tabular}{ccc}
\hline Purchased energy; & $\begin{array}{c}\text { Investment of } \\
\text { corresponding } \\
\text { non-renewable } \\
\text { primary energy; }\end{array}$ & $\begin{array}{c}\text { carbon } \\
\text { dioxide } \\
\text { emissions }\end{array}$ \\
\hline Oil & 1.3 & 0.095 \\
\hline Natural gas & 1.27 & 0.069 \\
\hline Coal & 1.2 & 0.133 \\
\hline $\begin{array}{c}\text { Solar energy (thermal } \\
\text { energy) }\end{array}$ & 3.07 & 0.14 \\
\hline $\begin{array}{c}\text { Solar energy (electricity } \\
\text { energy) }\end{array}$ & 0.14 & 0.06 \\
\hline
\end{tabular}

Conversion of materials leading to global warming: many gases can lead to climate warming. In the case, material leading to global warming-carbon dioxide is adopted as reference for standardizing global warming potential of other materials. Material emission leading to global warming is multiplied by its global warming potential. Then, they are added for obtaining total influence on global warning.

\begin{tabular}{lc}
\hline Materials; & \multicolumn{2}{c}{$\begin{array}{l}\text { Global warming potential (time span } \\
\text { of 100 years) }\end{array}$} \\
\hline Carbon dioxide & 1 \\
\hline Methane & 21 \\
\hline Nitrous oxide & 270 \\
\hline Sulfur hexafluoride & 23900 \\
\hline
\end{tabular}

3. Definition of denominator in indicators: In the paper, enterprise net cash flow from operating is selected as the financial performance indicator in the paper mainly because net sales refers to the balance of total sales after reduction of sales allowances, sales return and discount. Since production unit generally can not be associated with sales amount, it is controversial to regard sales as an indicator to measure factory performance.Therefore, performance value may be distorted. In addition, enterprises also can improve sales income through varnishing financial statements. The net cash flow from operating can make calculation of ecological efficiency indicator comparable 
more easily since the present value of enterprise net cash flow from operating is more objective and true. It is tightly related to the resource input, waste emission and output of product and labor in the operation process which can be actually controlled by the enterprise. Therefore, net cash flow from operating is selected as denominator in the calculation of the paper.

\begin{tabular}{cccc}
\hline Item & Year of 2013 & Year of 2012 & Year of 2011 \\
\hline Operating income (Yuan) & $19,279,979,584.18$ & $19,317,607,373.26$ & $17,764,855,169.66$ \\
\hline Net profit (Yuan) & $67,940,203.94$ & $866,186,548.69$ & $817,717,336.94$ \\
\hline $\begin{array}{c}\text { Net cash flow from operating } \\
\text { (Yuan) }\end{array}$ & $2,861,735,410.19$ & $4,027,086,722.20$ & $1,976,657,079.30$ \\
\hline $\begin{array}{c}\text { Earnings per share } \\
\text { (Yuan/share) }\end{array}$ & 0.076 & 0.965 & 1.005 \\
\hline Net assets return rate (\%) & $1.1 \%$ & $15.32 \%$ & $25.24 \%$ \\
\hline Total assets (Yuan) & $35,354,889,045.29$ & $29,468,018,142.58$ & $26,779,371,267.06$ \\
\hline
\end{tabular}

(Data source: Annual statements of Y enterprise in 2011, 2012 and 2013 )

Overcapacity in the fertilizer industry is an indisputable fact. Most chemical fertilizer enterprises suffer from certain loss under the situation. Hubei Yihua released 2013 annual report, and it shows that the company operating income was 19.279 billion Yuan with a decrease of $0.37 \%$ compared with that of last year. Net profits attributive to shareholders of the listed companies were 67.94 million Yuan with a decrease of 92.16\% compared with that of last year, net cash flow from business activities was 2861735410.19 Yuan in 2013 with a decrease of 29.21\% compared with that of last year main because the cash received from sales of commodity in the period was reduced compared with that of the last year. Yuntian Chemistry released 2012 annual report, and it shows that the company operating income was 19.317 billion Yuan with an increase of $8.74 \%$ compared with that of last year. Net profits attributive to shareholders of the listed companies were 866 million Yuan Yuan with an increase of 5.93\% compared with that of last year. The net cash flow from business activities was 4027086722.20 Yuan with an increase of $103.71 \%$ compared with that of last year.

\begin{tabular}{cccl}
\hline Item & Year of 2013 & Year of 2012 & Year of 2011 \\
\hline $\begin{array}{c}\text { Operating } \\
\text { income } \\
\text { (Yuan) }\end{array}$ & $19,279,979,584.18$ & $19,351,602,521.03$ & $17,764,855,169.66$ \\
\hline $\begin{array}{c}\text { Operating } \\
\text { income } \\
\text { (Yuan) }\end{array}$ & $16,445,613,632.83$ & $15,529,101,545.98$ & $14,408,631,975.43$ \\
\hline $\begin{array}{c}\text { Sales cost } \\
\text { (Yuan) }\end{array}$ & $844,900,685.53$ & $787,361,425.85$ & $752,574,493.47$ \\
\hline $\begin{array}{c}\text { Management } \\
\text { cost (Yuan) }\end{array}$ & $576,729,938.47$ & $578,049,924.22$ & $491,899,575.05$ \\
\hline $\begin{array}{c}\text { Financial } \\
\text { cost (Yuan) }\end{array}$ & $1,093,502,959.26$ & $826,991,598.42$ & $617,966,748.48$ \\
\hline $\begin{array}{c}\text { Investment } \\
\text { in research } \\
\text { and }\end{array}$ & $67,700,000.00$ & $61,000,000.00$ & $54,954,954.95$ \\
$\begin{array}{c}\text { development } \\
\text { (Yuan) }\end{array}$ & & & \\
\hline
\end{tabular}

( Data source: annual report of Y enterprise in 2011, 2012 and 2013 )

Company industry westward transfer strategy was implemented in 2012. 400000t synthetic ammonia and 600000t urea project of Xinjiang Company was put into operation and achieved production targets in the first year. Net profit of 296.9308 million Yuan was realized. Stage I work of $600000 t$ polyvinyl chloride and 500000t ionic membrane caustic soda project as well as supporting project of Xinjiang Company were completed for more than 95\%, which will be completed and put 
into production in the first half of 2013. In 2012, three trade companies under the company realized operating income of 1843,3295 million Yuan totally, and the profit was up to 16.3167 million Yuan. In 2012, the company comprehensively completed the production targets of leading products, including production of 3.3 million tons of urea, 725.9 thousand tons of DAP, 746.2 thousand tons of PVC and 62800 tons of pentaerythritol. The company produced 44900 tons of sodium hydrosulfite in 2012 and completed $64 \%$ of target due to market reason. The company produced 3.26 million tons of urea accounting for $98.78 \%$ of the annual plan, 1.43 million tons of diammonium phosphate accounting for $127.68 \%$ of annual plan, 960000 tons of polyvinyl chloride accounting for $104 \%$ of annual plan, 63000 tons of pentaerythritol accounting for $100 \%$ of annual plan, and 42000 tons of sodium hydrosulfite accounting for 84\% of annual plan in 2013. Operating income of 1.928 million Yuan was achieved accounting for $91.8 \%$ of annual plan. Production target of urea was not completed because natural gas supply was limited in winter. Production target of sodium hydrosulfite was not realized because the company actively limited production and maintained price. Operating income plan was not completed because of sales price reduction of fertilizer.

\begin{tabular}{|c|c|c|c|c|}
\hline $\begin{array}{l}\text { Product } \\
\text { category }\end{array}$ & Item & Amount in 2013 & Amount in 2012 & $\begin{array}{l}\text { Year-on-year } \\
\text { increase } \\
\text { or decrease }\end{array}$ \\
\hline Urea & Raw material & $1,626,668,861.80$ & $1,590,141,656.89$ & $-0.56 \%$ \\
\hline Urea & $\begin{array}{c}\text { Fuel and } \\
\text { power }\end{array}$ & $2,127,191,085.78$ & $2,069,432,426.22$ & $-0.08 \%$ \\
\hline Urea & $\begin{array}{l}\text { Manufacturing } \\
\text { cost }\end{array}$ & $510,508,162.12$ & $491,554,072.60$ & $0.95 \%$ \\
\hline Urea & Labor & $296,834,790.62$ & $293,808,307.43$ & $-1.79 \%$ \\
\hline Urea & Depreciation & $695,356,465.35$ & $664,773,231.24$ & $1.68 \%$ \\
\hline Urea & Total & $5,256,559,365.67$ & $5,109,709,694.37$ & $0.2 \%$ \\
\hline DAP & Raw material & $2,716,903,884.76$ & $2,100,434,150.19$ & $-0.03 \%$ \\
\hline DAP & $\begin{array}{c}\text { Fuel and } \\
\text { power }\end{array}$ & $42,051,496.57$ & $32,708,182.43$ & $-0.64 \%$ \\
\hline DAP & $\begin{array}{l}\text { Manufacturing } \\
\text { cost }\end{array}$ & $92,755,847.61$ & $71,578,776.05$ & $0.15 \%$ \\
\hline DAP & Labor & $52,005,633.49$ & $40,292,688.51$ & $-0.25 \%$ \\
\hline DAP & Depreciation & $163,088,558.43$ & $125,144,350.18$ & $0.72 \%$ \\
\hline DAP & Total & $3,066,805,420.86$ & $2,370,158,147.36$ & $-0.06 \%$ \\
\hline
\end{tabular}

(Data source: Annual statement of Y enterprise in 2011, 2012 and 2013)

Data in the above table is analyzed. It is concluded that consumption of raw material, power and fuel accounts for $70 \%$ of total cost in the production link of urea, wherein raw material accounts for $30.95 \%$, power and fuel accounts for $40.47 \%$, much greenhouse gas can be produced if so much fuel and power are completely burned, which is contrary to energy saving and discharge reduction policy. After the primary energy is converted into value at the same order, the proportion of net cash flow produced in current business activity should be regarded as basis for analysis.

\begin{tabular}{|c|c|c|c|c|}
\hline Name & Unit & $\begin{array}{c}\text { Tons } \\
\text { in } \\
2013\end{array}$ & $\begin{array}{c}\text { Tons } \\
\text { in } \\
2012\end{array}$ & $\begin{array}{c}\text { Tons } \\
\text { in } \\
2011\end{array}$ \\
\hline Coal & $\begin{array}{c}\text { Ten thousand } \\
\text { tons }\end{array}$ & 796.45 & 785.61 & 600.24 \\
\hline Natural gas & $\begin{array}{c}\text { Hundred million } \\
\text { cubic meters }\end{array}$ & 1.26 & 1.09 & 0.78 \\
\hline $\begin{array}{c}\text { Purchased } \\
\text { electricity }\end{array}$ & $\begin{array}{c}\text { Hundred million } \\
\text { KWH }\end{array}$ & 32.12 & 30.6 & 26.18 \\
\hline Raw water & $\begin{array}{c}\text { Hundred million } \\
\text { cubic meters }\end{array}$ & 0.5 & 0.45 & 0.34 \\
\hline
\end{tabular}


Various energies should be converted into standard coal according to energy conversion standard of national standard administration aiming at primary energy usage. The conversion standards are shown as follows: raw coal $1 \mathrm{~kg}=$ standard coal $0.714 \mathrm{~kg}$, coking coal $1 \mathrm{~kg}=$ standard coal $0.971 \mathrm{~kg}$, heavy oil $1 \mathrm{~kg}$ = standard coal $1.429 \mathrm{~kg}$, crude oil $1 \mathrm{~kg}$ = standard coal $1.429 \mathrm{~kg}$, then the standard coal can be converted into heat (standard coal $1 \mathrm{~kg}$ contains heat $7000 \mathrm{kcal}$ ), and heat is finally converted into KWH (1kcal $=1.163 * 10$ [-3] kilowatt hours $)$.

Primary energy coal usage in $2013=7964500000 \mathrm{~kg} \times 0.714 \times 7 \quad 000 \mathrm{kcal} \times 1.163 \times 10[-3] \mathrm{kilowatt}$ hour $=46300273480 \mathrm{~kg}$. Primary energy natural gas usage $=126000000 \times 0.35 \times 8500$ kcal $\times 1.163 \times 10[-3]$ kilowatt hour $=435950550 \mathrm{~kg}$. Primary energy consumption $/$ net cash flow from operating $=(46300273480+435950550) / 2,861,735,410.19=16.3314 \mathrm{~kg} / /$ Yuan. Water dosage/ net cash flow from operating $=50000000 / 2,861,735,410.19=0.0174 \mathrm{~m} 3 /$ Yuan.

Primary energy coal usage in $2012==7856100000 \mathrm{~kg} \times 0.714 \times 7000 \mathrm{kcal} \times 1.163 \times 10[-3] \mathrm{kilowatt}$ hour $=45664948211.4 \mathrm{~kg}$. Primary energy natural gas usage $=109000000 \times 0.35 \times 8500$ $\mathrm{kcal} \times 1.163 \times 10[-3] \mathrm{kilowatt}$ hour $=377131825 \mathrm{~kg}$. Primary energy consumption $/$ net cash flow from operating $=45664948211.4+377131825) / 4,027,086,722.20=11.433 \mathrm{~kg} /$ Yuan. Water dosage $/$ net cash flow from operating $=45000000 / 4,027,086,722.20=0.01113 /$ Yuan.

Primary energy coal usage in $2011=6002400000 \mathrm{~kg} \times 0.714 \times 7000 \mathrm{kcal} \times 1.163 \times 10[-3]$ kilowatt hour $=34889994417.6 \mathrm{~kg}$. Primary energy natural gas dosage $=78000000 \times 0.35 \times 8500$ $\mathrm{kcal} \times 1.163 \times 10[-3]$ kilowatt hour $=269874150 \mathrm{~kg}$. Primary energy consumption $/$ net cash flow from operating $=(34889994417.6+269874150) / 1,976,657,079.30=17.7875 \mathrm{~kg} /$ Yuan. Water dosage $/$ net cash flow from operating $=34000000 / 1,976,657,079.30=0.0172 \mathrm{~m} 3 /$ Yuan.

The above data is analyzed. Indicators of Hubei Yihua in recent three years can be observed. Company's cash flow in 2012 was significantly higher than that of 2011 and 2013. Though fertilizer annual production of the company was increased in 2013, energy dosage was increased, operating activity ability in the year was slightly decreased compared with previous period, the net cash flow from operating was significantly decreased compared with that in 2012. Therefore, primary energy dosage was increased compared with that of 2012 in the evaluation indicators. However, low carbon indicators did not have magnitude difference. The above indicators reflect that Hubei Yihua had too high combustion of fossil fuels t before 2012, and primary energy consumption was huge, and inestimable impact was produced on the environment.

Data shows that a lot of fossil energies are used for providing power in distillation, during and other links during production. The proportion of coal is far more than that of natural gas in the energy structure of factory. Natural gas is relatively clean energy, and its cost is lower than coal. Natural gas is massively used as main energy supply raw materials in the United States-a major power for fertilizer manufacturing and Middle East, thereby greatly reducing production cost of manufacturers. Most fertilizer made in China is exported to Asia, Latin America and other regions with low profit rate.

In China, fertilizer industry profit rate was generally higher in 2010 and 2011, and the profit of each ton of urea is not higher than 100 Yuan aiming at the profit space of fertilizer manufacturer from each ton of fertilizer. However, the profit rate of foreign manufacturers is always 5 to 6 times higher than our profit rate. It is the reason why the quotation of foreign manufacturers is much lower than the quotation of China fertilizer manufacturers in fertilizer export trade quotation. However, once the international market suffers from turmoil, foreign manufacturers enjoy much higher price reduction space compared with that of China fertilizer manufacturers. Fertilizer production encountered severe overcapacity since 2013. The market conditions remained low level, a large number of small fertilizer workshops were threatened by production suspension and even collapse. In addition, China's customs organ cancelled tariff window period and adopted the policy of unified tariffs throughout the year in 2015. The competition in domestic chemical fertilizer market was more brutal, thereby leading to the situation that 'loss is produced from production, and more loss is produced if production is suspended'. We begin to adjust energy structure, and optimize product production equipment. It is urgent to use high-quality and environment protection energy, and increase development efforts and investment. 


\section{Experience and reference of environmental cost management in Y Enterprise}

Environmental protection is an important content for sustainable development of the enterprise. Y Enterprise insists on giving equal attention to development and environmental protection. Circular economy industrial chain is constructed. Three major chemical industry main businesses of coal, phosphorus and salt as well as intermediate products are used alternately and they are mutually interlinked, thereby guaranteeing product line extension and in-depth development; Resource-efficient economy as well as energy conservation and emission reduction model production system are established. Coal, phosphorus and other mineral resources were saved by more than ten thousand tons in 2012. Water resources were saved by 50 million tons, waste emission of about 1 million tons was reduced, thereby creating good social benefits. Technological innovation is the most fundamental measure in energy saving and emission reduction. The company actively carries out terminal governance, spends huge investment to construct wastewater biochemical treatment systems in all major industrial parks. Meanwhile, a circular economy new path of 'circulated water consumption, scientific gas consumption, comprehensive utilization and structure optimization' was created through constantly introducing advanced foreign technology and strengthening independent innovation. Y Enterprise widely implements 'green enterprise' activity. Culture of energy saving and efficiency increasing is deeply cultivated to each employee. 'Energy-saving slogan and comic', etc. summarized by employees in work can be observed anywhere in the factory. Material consumption is converted to value idea which is acceptable to employees. Influence of tiny waste is reminded to employees vividly, and employee behaviors can be subtly constrained. The company continuously and constantly strengthens enforcement efforts of the system, and always attaches great importance to environment management. 'Three-wastes and noise control management procedures', 'zone environmental protection monitoring management system', 'radiation source management standard', 'environmental information management standard', 'management standard of general solid waste', 'online monitoring system management system', 'environment protection comprehensive management system', 'environment protection facility management standard', 'risky waste management standard', 'environmental protection facility production machine-hour management system' and other systems are established. Impersonality concept is strictly followed during implementation. Any person violating the system should be strictly punished. Area around the factory should be monitored and notified in real time aiming at disclosure of environment information. Enterprise environment information should be regularly notified to the public, which should be reported in financial statements and social responsibility report.

\section{References}

[1]. Xiao Xu. Environmental cost theory [M] China Financial Economic Publishing House, 2002;

[2]. Christine Jasch. The use of environmental Management Accounting (EMA) for identifying environmental costs [J].Journal of Cleaner Production, 2002, Vol.11 (6):667-676

[3]. Xu Shengping. Environmental cost management performance evaluation model based on product life cycle [j]. Zhejiang University Press, 2007.

[4]. Collins C.Ngwakwe. Justifying Environmental Cost Allocation in a Multiple Product Firm: A Case Study[J]. Managing Global Transitions, 2009, Vol.7 (4):403

[5]. Xie Dongming, Wang Ping. Research on strategy control of China enterprise environmental cost under ecological economy development mode [J]. Accounting Research, 2013, (3):88 94. 